TAPROBANICA, ISSN 1800-427X. November, 2021. Vol. 10, No. 02: pp. 138-139.

(C) Research Center for Climate Change and Department of Biology, Faculty of Mathematics \& Natural Sciences, University of Indonesia, Depok 16424, INDONESIA.

http://www.taprobanica.org

https://doi.org/10.47605/tapro.v10i2.268

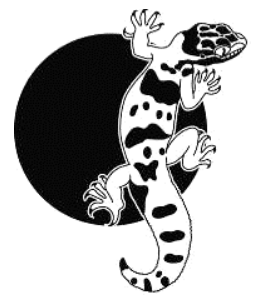

\section{An unusual roosting habit of a painted bat (Kerivoula picta) from Sri Lanka}

The painted bat, Kerivoula picta (Pallas, 1767) is considered one of the most aesthetically appealing bats in Sri Lanka with bright orange fur and black wings. However, very little information is available with regard to the ecology of this species in both local and global contexts. Of its roosting habits, Phillips (1980) reports that in Sri Lanka the bat is usually found roosting among banana leaves while it has been observed utilising tall grass species and even an abandoned nest of a Baya Weaver (Plocius philippinus) for this purpose (Bates \& Harrison 1997, Sharma 1986). Here we report an observation of the species using a man-made artefact for roosting during the day.

The roost was found on 22 May 2015 at Pathaha (6.7068N, 80.9089E; alt. 239 m a.s.1.), Soragune, Sri Lanka at $1624 \mathrm{~h}$ and observations were made of it roosting for two days. Photographs were obtained using a Sony Alpha digital SLR camera fitted with an 18-55 mm lens. Identification of the species was based on Phillips (1980) and Bates \& Harrison (1997). Utmost care was taken to not disturb the bat when photographed and other data were obtained and at no point was the animal handled.

A single individual of $K$. picta was observed at this day roost (Fig. 1). The roost used was a small, brightly coloured cloth that was attached to a horizontal wire which demarcated the boundary of a rice paddy field (Fig. 1). The wire on which the cloth was attached had many other similar sized cloths attached to it at roughly $1 \mathrm{~m}$ intervals but only this cloth was constructed into a cone shape. The wire was placed approximately $1.5 \mathrm{~m}$ from the ground. The cloth used for the roost itself was constructed crudely in the shape of a cone that was $30 \mathrm{~cm}$ high and $11 \mathrm{~cm}$ wide at the base (Fig. 2).

The time of observation and relative roosting position of the bat within the cone is presented in Table 1.

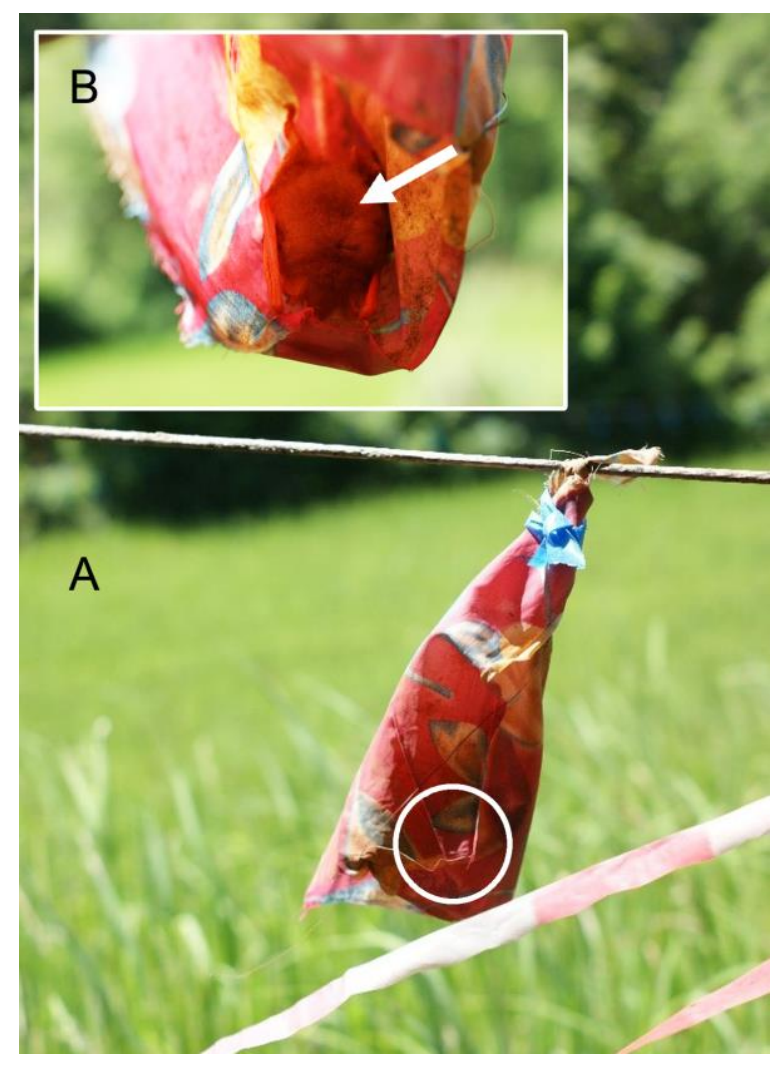

Figure 1. (A) The artificial roost (a man-made cloth) attached to a wire by a rice paddy field in Sri Lanka; (B) the painted bat Kerivoula picta in roost.

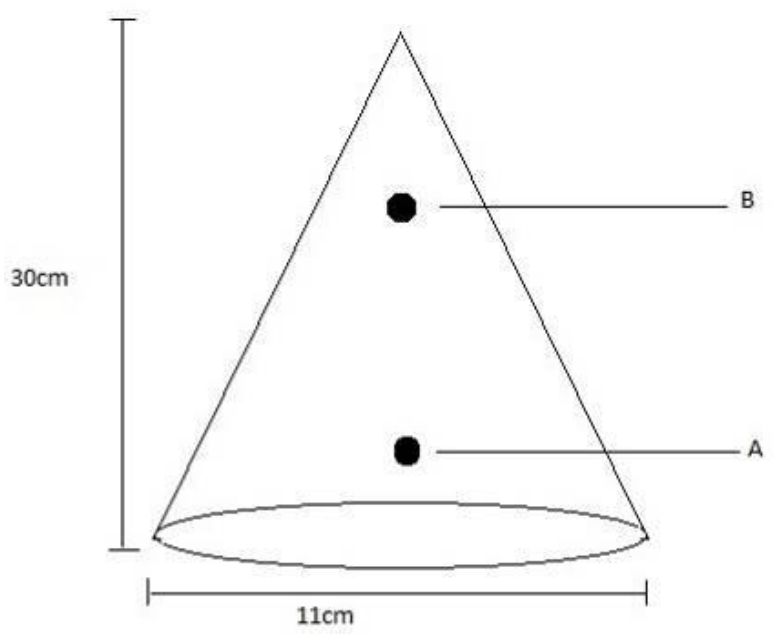

Figure 2. Diagram of the roost with positions at which the painted bat was observed for 2 days. 
Table 1. The date, time and relative position of the painted bat within the artificial roost; Positions A and $\mathrm{B}$ are indicated in figure 2 ; the roost was unoccupied for the remainder of 24 May 2015.

\begin{tabular}{cc}
\hline $\begin{array}{c}\text { Date and time of } \\
\text { observation }\end{array}$ & Position in roost \\
\hline 22 May 2015: $1625 \mathrm{~h}$ & $\mathrm{~A}$ \\
23 May 2015: $0900 \mathrm{~h}$ & $\mathrm{~A}$ \\
23 May 2015: $1545 \mathrm{~h}$ & $\mathrm{~B}$ \\
23 May 2015: $1808 \mathrm{~h}$ & $\mathrm{~B}$ \\
24 May 2015: $0735 \mathrm{~h}$ & roost empty \\
\hline
\end{tabular}

As far as we know, in Sri Lanka, this is the first record of the species utilising an artificial structure as a roosting site. Many authors have reported the use of natural roosts ranging from banana leaves, most commonly, (Sripathi et al. 2006, Phillips 1980, Bates \& Harrison 1997) to abandoned bird nests (Sharma 1986) from Sri Lanka. Phillips (1980) reports that the choice of banana leaves as a day roost renders the animal well camouflaged. This was quite evident in our observation as well as the colour of the cloth in which it roosted blended well with the striking pelage of the animal. Our observations suggest that the animal uses its day roost between the hours of $0900 \mathrm{~h}$ to $1830 \mathrm{~h}$. However, more observations are required before establishing a proper timescale of roost use for the species. The roost adjacent to a paddy field places the bat within a convenient distance from a large supply of insects, on which it feeds (Phillips 1980). The use of such a roost demonstrates the ability of this species to adapt to given circumstances and exploit opportune conditions.

\section{Literature cited}

Bates, P.J.J. and D.L. Harrison (1997). Bats of the Indian sub-continent. Harrison Zoological Museum, London: 212pp.

Phillips, W.W.A. (1980). Manual of the mammals of Sri Lanka: Part 1 ( $2^{\text {nd }}$ revised ed.). Wildlife \& Nature Protection Society of Sri Lanka, Colombo: 267pp.

Sharma, S.K. (1986). Painted bats and nests of baya weaver bird. Journal of Bombay Natural History Society, 83(suppl.): 196.

Sripathi, K., H. Raghuram, and P. Nathan (2006). Echolocation sounds of the painted bat Kerivoula picta (Vespertilionidae). Current Science, 91(9): 1145-1147.

Submitted: 16 Aug. 2021, Accepted: 9 Sep. 2021 Section Editor: Burton Lim

R.K. de $\mathrm{Mel}^{1}$, A.P. Sumanapala ${ }^{2}$, H.D. Jayasinghe ${ }^{1,3}$, S.S. Rajapakshe ${ }^{3}$ \& R.P. Nanayakkara ${ }^{4}$

${ }^{1}$ National Institute of Fundamental Studies, Hanthana Road, Kandy, Sri Lanka E-mail: ruvinda_demel@hotmail.com

${ }^{2}$ Department of Zoology \& Environmental Sciences, University of Colombo, Sri Lanka

${ }^{3}$ Butterfly Conservation Society of Sri Lanka, 762/A, Yatihena, Malwana, Sri Lanka

${ }^{4}$ Biodiversity Education \& Research (BEAR), 92/2, Ananda Rajakaruna Mw., Colombo 10, Sri

Lanka 